\title{
Ellagic Acid (EA), a Tannin Was Isolated From Eucalyptus Citriodora Leaves and Its Anti- Inflammatory Activity
}

\section{Qiujian Yu}

South China University of Technology

\section{Zongcai Feng}

Lingnan Normal University

\section{Liping Huang}

Lingnan Normal University

Jingwei He

South China University of Technology

\section{Zhongliu Zhou}

Lingnan Normal University

Fang Liu ( $\nabla$ mcfliu@126.com )

South China University of Technology

\section{Research Article}

Keywords: Eucalyptus Citriodora, Ellagic Acid, Anti-inflammatory, Anti-gastric Ulcer

Posted Date: September 2nd, 2021

DOI: https://doi.org/10.21203/rs.3.rs-849957/v1

License: (c) (i) This work is licensed under a Creative Commons Attribution 4.0 International License. Read Full License 


\title{
Ellagic acid (EA), a tannin was isolated from Eucalyptus citriodora \\ leaves and its anti-inflammatory activity
}

\author{
Yu Qiujian ${ }^{1}$, Feng Zongcai ${ }^{2}$, Huang Liping ${ }^{2}$, He Jingwei ${ }^{1}$, Zhou Zhongliu ${ }^{2 *}$, Liu Fang ${ }^{1^{*}}$
}

\begin{abstract}
:
A tannin, EA (1), and other nine non-tannins compounds, gallic acid (2), quercetin (3), myricetin (4), 3-O-methylellagic acid 4'-O- $\alpha$-L-rhamnopyranoside (5), quercetin-3-O$\beta$-D-galactopyranoside (6), kaempferol-3-O- $\beta$-D-glucoside (7), quercetin 3-O- $\beta$-Dglucuronide (8), quercetin-3-O-rutinoside (9), 3,3',4-tri-O-methylellagic acid-4'-O- $\beta$ D-glucopyranosyl (10) were isolated from a valuable medicinal plant, Eucalyptus citriodora. Structural identification of these compounds was conducted using ${ }^{1} \mathrm{H}$ NMR and ${ }^{13} \mathrm{C}$ NMR spectroscopy and comparing their spectral data with those previously reported in literatures. The anti-inflammatory effects of EA were evaluated in ethanolinduced acute gastric ulcer mice models in our study. The result demonstrated that the intragastric administration of EA significantly prevented the gastric ulceration caused by ethanol treatments. Especially, the gastric tissue in the middle dose EA (100 mg/kg) showed few ulcerations with only slight focal congestion which indicated that it has a significant protective effect on gastric ulcer by increasing the IL-10 and $\mathrm{PGE}_{2}$ levels, and reducing the IL- 6 , TNF- $\alpha$, GAS and COX-2 levels. In addition, the middle-dose EA has no adverse effect on liver and kidney. These findings imply that EA exerts gastroprotective effects by means of its anti-inflammatory effects and may be a potential drug for anti-ulcer treatment.
\end{abstract}

Keywords Eucalyptus Citriodora · Ellagic Acid · Anti-inflammatory · Anti-gastric Ulcer

\section{Introduction}

The gastric ulcer is a common disorder with multiple causes including the infection from Helicobacter pylori, indiscriminate use of nonsteroidal anti-inflammatory drugs (NSAIDs), irregular diet, excessive alcohol consumption and pepsin and gastric acid secretion and is mainly occurs in the stomach and duodenum [1]. Nowadays, it is

\footnotetext{
$\square$ Liu Fang

mcfliu@126.com

Zhou Zhongliu

zlzhou@hotmail.com

${ }^{1}$ School of Material Science and Engineering, South China University of Technology, Guangzhou, 510641

${ }^{2}$ School of Chemistry and Chemical Engineering, Lingnan Normal University, Zhanjiang, 524048
} 
commonly believed that gastric ulcer therapy is generally focused on inhibiting gastric acid secretion involved in suppressing the secretion of interleukin-6 (IL-6), tumor necrosis factor-alpha (TNF- $\alpha$ ) and stimulate mucosal defense mechanism [2]. However, many of existed medicines have side effects and limitations, including the antibiotics used to eradicate Helicobacter pylori and the proton pump inhibitors [3].

In recent years, a lot of research has been accomplished to develop natural products with anti-ulcer activity, which may provide a rich source of new anti-ulcer drugs [4]. A few plant extracts and plant-derived compounds have been identified and confirmed to have powerful anti-ulcer activity with safety [5]. Among a broad reach of natural molecules, dietary polyphenols have a variety of biological mechanisms and play a pivotal role in the treatment of gastric and duodenal ulcers.

Eucalyptus citriodora is a medicinal plant that belongs to the Myrtle family and is found in Australia and some oriental countries, especially China. Among the polyphenol compounds extracted from Eucalyptus citriodora, Ellagic acid (EA), a phenolic lactone compound, exhibits anti-inflammatory, antioxidant, hepatoprotective, and anti-mutagenic effects. EA could decrease gastric ulcer and bleeding induced by ethanol in which attributing to the enhancement of NO production [6]. Furthermore, EA have abilities to reduce stress gastric injury and inhibit gastric acid secretion significantly [7]. In the present study, we evaluated the antiulcerogenic effects of different doses of EA extracted from Eucalyptus citriodora against ethanol-induced gastric ulcer and to investigate its effects on inflammatory cytokines, including IL-6, IL-10, TNF- $\alpha$, GAS, COX-2 and PGE $_{2}$.

\section{Results}

\section{Identification of Isolated Compounds}

Ten compounds were isolated and identified in the 95\% EtOH extracts of the Eucalyptus citriodora leaves (Fig.1). These compounds were identified by spectroscopic analyses, including MS and NMR spectroscopy and comparing their spectral data with those previously reported in literature.

Compound 1: Pale yellow powder. ${ }^{1} \mathrm{H}$ NMR (400 MHz, DMSO-d6): $\delta 7.90(1 \mathrm{H}, \mathrm{s}$, H-5'), 7.70 (1H, s, H-5), 5.61-5.21 (4H, m, Glu-2", 3",4", 5"), 5.17 (1H, d, J = 5.4 Hz, Glu-1"), 4.17 (3H s, 3'- $\left.\mathrm{OCH}_{3}\right), 4.11\left(3 \mathrm{H}, \mathrm{s}, 3-\mathrm{OCH}_{3}\right), 4.07\left(3 \mathrm{H}, \mathrm{s}, 4-\mathrm{OCH}_{3}\right) .{ }^{13} \mathrm{C} \mathrm{NMR}^{-1}$ (100 MHz, DMSO-d6): $\delta$ 112.43(C-1), 142.18(C-2), 141.67(C-3,3'), 152.36(C-4), 112.79(C-5), 113.32 (C-6), 158.89(C-7), 113.10(C-1'), 141.36(C-2'), 154.79(C-4'), 108.03 (C-5'), 114.12(C-6'), 158.65(C-7'), 101.71(C-1"), 73.78(C-2"), 77.73(C-3"), 69.93(C-4"), 76.93(C-5"), 60.99(C-6"), 61.81(3-OCH 3$), 62.16\left(3^{\prime}-\mathrm{OCH}_{3}\right), \quad 57.25(4-$ $\left.\mathrm{OCH}_{3}\right)$ 。 By comparison with literature data [8], compound 1 was determined to be 3,3',4-tri-O-methylellagic acid-4'-O- $\beta$-D-glucopyranosyl.

Compound 2: White needle crystals. ${ }^{1} \mathrm{H}$ NMR (400 MHz, DMSO-d6): $\delta 7.72(1 \mathrm{H}$, s, H-5'), 7.51 (1H, s, H-5), 5.48 (1H, s, Glu-1"), 4.94 (1H, d, J = 5.6 Hz, H-3'), $4.72(1 \mathrm{H}$, $\mathrm{d}, \mathrm{J}=6.1 \mathrm{~Hz}, \mathrm{H}-4), 4.05\left(3 \mathrm{H}, \mathrm{s}, 3-\mathrm{OCH}_{3}\right), 1.15\left(3 \mathrm{H}, \mathrm{d}, \mathrm{J}=6.2 \mathrm{~Hz}, \mathrm{Glu}-5 "-\mathrm{CH}_{3}\right) .{ }^{13} \mathrm{C}$ 
NMR (100 MHz, DMSO-d 6 ): $\delta 114.67$ (C-1), 136.54(C-2), 140.53(C-3), 153.11(C-4), 111.98 (C-5), 111.70(C-6), 159.12(C-7), 107.50(C-1'), 141.74(C-2'), 142.21(C-3'), 146.89 (C-4'), 111.91(C-5'), 113.40 (C-6'), 159.08(C-7'), 100.57(C-1"), 70.40(C-2"), 70.53(C-3"), 72.24(C-4"), 70.33(C-5"), 18.33(C-6"), 61.40(3-OCH 3$)$. From the comparison of these data with those reported in the literature [9], compound 2 was identified as 3-O-methylellagic acid 4'-O- $\alpha$-L-rhamnopyranoside.

Compound 3: White powder. ${ }^{1} \mathrm{H}$ NMR (400 MHz, DMSO-d6): $\delta 12.23(1 \mathrm{H}, \mathrm{s}$, $\mathrm{COOH}), 9.18(2 \mathrm{H}, \mathrm{s}, 3,5-\mathrm{OH}), 8.83(1 \mathrm{H}, \mathrm{s}, 4-\mathrm{OH}), 6.92(2 \mathrm{H}, \mathrm{s}, \mathrm{H}-2,6) .{ }^{13} \mathrm{C}$ NMR $(101$ MHz, DMSO-d6) $\delta$ 167.91(C=O), 145.86(C-3,5), 138.44(C-4), 120.89(C-1), 109.17(C2,6). By comparison with literature data [10], compound $\mathbf{3}$ was determined to be gallic acid.

Compound 4: Pale yellow powder. ${ }^{1} \mathrm{H}$ NMR (400 MHz, DMSO-d6): $\delta 7.47$ (2H, s, H-5,5'). ${ }^{13} \mathrm{C}$ NMR (100 MHz, DMSO-d6): $\delta$ 108.02(C-1,1'), 140.17(C-2,2'), 136.84(C3,3'), 148.60(C-4,4'), 110.66(C-5,5'), 112.81(C-6,6'), 159.63(C-7,7'). By comparison with literature data [11], compound 4 was identified as EA.

Compound 5: Yellow powder. ${ }^{1} \mathrm{H}$ NMR (400 MHz, DMSO-d6): $\delta 6.45(1 \mathrm{H}, \mathrm{d}, \mathrm{J}=$ $\left.2.1 \mathrm{~Hz}, \mathrm{H}-8), 6.24(1 \mathrm{H}, \mathrm{d}, \mathrm{J}=2.1 \mathrm{~Hz}, \mathrm{H}-6), 7.59(1 \mathrm{H}, \mathrm{d}, \mathrm{J}=2.2 \mathrm{~Hz}, \mathrm{H}-2)^{\prime}\right), 6.88(1 \mathrm{H}, \mathrm{d}$, $\left.\mathrm{J}=8.5 \mathrm{~Hz}, \mathrm{H}-5^{\prime}\right), 7.73\left(1 \mathrm{H}, \mathrm{dd}, \mathrm{J}=8.5,2.3 \mathrm{~Hz}, \mathrm{H}-6^{\prime}\right), 5.43$ (1H, d, J = $\left.7.7 \mathrm{~Hz}, \mathrm{H}-1^{\prime \prime}\right)$, 3.83-3.24 (4H, protons of galactopyranoside) 1.29 (2H, s, H-6"). ${ }^{13} \mathrm{C}$ NMR (100 MHz, DMSO-d6): $\delta$ 156.82(C-2), 133.89(C-3), 177.84 (C-4), 161.66(C-5), 99.32(C-6), 165.33(C-7), 94.06(C-8), 156.58(C-9), 104.11(C-10), 121.51(C-1'), 115.65(C-2'), 149.01(C-3'), 145.33(C-4'), 116.35(C-5'), 122.43(C-6'), 102.32(C-1"), 71.67(C-2"), 73.65(C-3"), 68.37(C-4"), 76.29(C-5"), 60.58(C-6"). From the comparison of these data with those reported in the literature [12], compound 5 was identified as quercetin-3-O$\beta$-D-galactopyranoside.

Compound 6: Yellow powder. ${ }^{1} \mathrm{H}$ NMR (400 MHz, DMSO-d6): $\delta 12.50$ (1H, s, 5$\mathrm{OH}), 10.79(1 \mathrm{H}, \mathrm{s}, 7-\mathrm{OH}), 9.60\left(1 \mathrm{H}, \mathrm{s}, 3^{\prime}-\mathrm{OH}\right), 9.37(1 \mathrm{H}, \mathrm{s}, 3-\mathrm{OH}), 9.32\left(1 \mathrm{H}, \mathrm{s}, 4^{\prime}-\mathrm{OH}\right)$, $7.69\left(1 \mathrm{H}, \mathrm{d}, \mathrm{J}=2.3 \mathrm{~Hz}, \mathrm{H}-2^{\prime}\right), 7.55\left(1 \mathrm{H}, \mathrm{dd}, \mathrm{J}=8.5,2.2 \mathrm{~Hz}, \mathrm{H}-6{ }^{\prime}\right), 6.89(1 \mathrm{H}, \mathrm{d}, \mathrm{J}=8.5$ $\mathrm{Hz}, \mathrm{H}-5$ ') $6.42(1 \mathrm{H}, \mathrm{d}, \mathrm{J}=2.1 \mathrm{~Hz}, \mathrm{H}-8), 6.20(1 \mathrm{H}, \mathrm{d}, \mathrm{J}=2.1 \mathrm{~Hz}, \mathrm{H}-6) .{ }^{13} \mathrm{C}$ NMR $(100$ MHz, DMSO-d6): $\delta$ 147.26(C-2), 136.19(C-3), 176.30(C-4), 161.18(C-5), 98.64(C-6), 164.34(C-7), 93.80(C-8), 156.59(C-9), 103.47(C-10), 122.41 (C-1'), 115.52(C-2'), 145.51(C-3'), 148.16(C-4'), 116.06(C-5'), 120.43(C-6'). By comparison with literature data [13], compound 6 was identified as quercetin.

Compound 7: Yellow powder. ${ }^{1} \mathrm{H}$ NMR (400 MHz, Methanol-d4): $\delta 7.67$ (1H, d, J $\left.=2.2 \mathrm{~Hz}, \mathrm{H}-2^{\prime}\right), 7.65-7.61\left(1 \mathrm{H}, \mathrm{m}, \mathrm{H}-6^{\prime}\right), 6.87\left(1 \mathrm{H}, \mathrm{d}, \mathrm{J}=8.4 \mathrm{~Hz}, \mathrm{H}-5^{\prime}\right), 6.40(1 \mathrm{H}, \mathrm{d}, \mathrm{J}$ $=2.1 \mathrm{~Hz}, \mathrm{H}-8), 6.21(1 \mathrm{H}, \mathrm{d}, \mathrm{J}=2.1 \mathrm{~Hz}, \mathrm{H}-6), 5.10(1 \mathrm{H}, \mathrm{d}, \mathrm{J}=7.6 \mathrm{~Hz}, \mathrm{H}-1 "), 4.52(1 \mathrm{H}$,

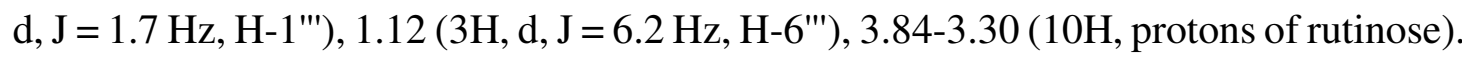
${ }^{13} \mathrm{C}$ NMR (100 MHz, Methanol-d4): $\delta$ 157.93(C-2), 134.21(C-3), 177.52 (C-4), 161.78(C-5), 98.66(C-6), 164.96(C-7), 93.54(C-8), 157.14(C-9), 104.06(C-10), 121.79(C-1'), 114.66(C-2'), 144.45(C-3'), 148.44(C-4'), 116.27(C-5'), 122.15(C-6'), 103.34(C-1"), 70.70(C-2"), 75.82(C-3"), 70.82(C-4"), 76.78(C-5"), 67.16(C-6"), 101.02(C-1"'), 74.31(C-2"), 69.99(C-3"'), 72.52(C-4"'), 68.31(C-5"'), 16.48(C-6"'). Вy comparison with literature data [14], compound 7 was determined to be quercetin-3-Orutinoside. 
Compound 8: Brown yellow powder. ${ }^{1} \mathrm{H}$ NMR (400 MHz, DMSO-d6): $\delta 12.51$ (1H, s, H-5), 10.80 (1H, s, H-7), 9.35 (1H, s, H-4'), 9.23 (2H, s, H-3',5'), 8.82 (1H, s, H-3), 7.25 (2H, s, H-2',6'), $6.38(1 \mathrm{H}, \mathrm{d}, \mathrm{J}=2.1 \mathrm{~Hz}, \mathrm{H}-8), 6.19(1 \mathrm{H}, \mathrm{d}, \mathrm{J}=2.1 \mathrm{~Hz}, \mathrm{H}-6)$. ${ }^{13} \mathrm{C}$ NMR (100 MHz, DMSO-d6): $\delta$ 147.30(C-2), 136.33(C-3,4'), 176.23(C-4), 161.19(C-5), 98.61(C-6), 164.33(C-7), 93.65(C-8), 156.54(C-9), 103.44(C-10), 121.24(C-1'), 107.62(C-2',6'), 146.18(C-3',5'). By comparison with literature data [15], compound $\mathbf{8}$ was identified as myricetin.

Compound 9: Yellow powder. ${ }^{1} \mathrm{H}$ NMR(400 MHz, DMSO-d6): $\delta 12.51(1 \mathrm{H}, \mathrm{s}, 5-$ $\mathrm{OH}), 8.04\left(2 \mathrm{H}, \mathrm{d}, \mathrm{J}=8.9 \mathrm{~Hz}, \mathrm{H}-2^{\prime}, 6^{\prime}\right), 6.87\left(2 \mathrm{H}, \mathrm{d}, \mathrm{J}=8.9 \mathrm{~Hz}, \mathrm{H}-3^{\prime}, 5^{\prime}\right), 6.41(1 \mathrm{H}, \mathrm{d}, \mathrm{J}=$ $2.1 \mathrm{~Hz}, \mathrm{H}-8), 6.19(1 \mathrm{H}, \mathrm{d}, \mathrm{J}=2.0 \mathrm{~Hz}, \mathrm{H}-6), 5.45(1 \mathrm{H}, \mathrm{d}, \mathrm{J}=8.0 \mathrm{~Hz}, \mathrm{H}-1 "), 3.45-3.23(4 \mathrm{H}$, m, H-2", 3", 4",5"). ${ }^{13} \mathrm{C}$ NMR(100MHz, DMSO-d6): $\delta$ 156.84(C-2), 133.61(C-3), 177.80(C-4), 161.57(C-5), 99.26(C-6), 164.85(C-7), 94.21(C-8), 160.54(C-9), 104.30(C-10), 121.10(C-1'), 131.44(C-2', 6'), 115.59(C-3', 5'), 156.81(C-4'), 101.64(C1"), 76.47 (C-2"), 75.76(C-3"), 72.15(C-4"), 74.36 (C-5"), 171.05(C-6"). From the comparison of these data with those reported in the literature [16], compound 9 was identified as kaempferol-3-O- $\beta$-D- glucoside.

Compound 10: Yellow powder. ${ }^{1} \mathrm{H}$ NMR $(400 \mathrm{MHz}, \mathrm{DMSO}-\mathrm{d} 6): \delta 12.51(1 \mathrm{H}, \mathrm{s}$, 5-OH), 7.86(1H, s, H-2'), 7.70-7.46 (1H, m, H-6'), 6.86(1H, d, J=8.5Hz, H-5'), 6.41(1H, $\mathrm{d}, \mathrm{J}=2.0 \mathrm{~Hz}, \mathrm{H}-8), 6.19(1 \mathrm{H}, \mathrm{d}, \mathrm{J}=2.1 \mathrm{~Hz}, \mathrm{H}-6), 5.46(1 \mathrm{H}, \mathrm{d}, \mathrm{J}=8 \mathrm{~Hz}$, Glu-H-1"), 3.903.18(4H, m, Glu-H-2", 3", 4", 5"). ${ }^{13} \mathrm{C}$ NMR (100 MHz, DMSO-d6): $\delta$ 157.28(C-2), 133.98(C-3), 177.84(C-4), 161.51(C-5), 99.31(C-6), 165.9(C-7), 94.13(C-8), 156.83(C-9), 104.24(C-10), 121.74(C-1'), 115.78(C-2'), 145.34(C-3'), 149.02(C-4'), 117.35(C-5'), 121.15(C-6'), 102.36(C-1"), 75.4(C-2"), 75.58(C-3"), 72.03(C-4"), 76.68(C-5"), 171.59(C-6"). By comparison with literature data [17], compound $\mathbf{1 0}$ was identified as quercetin 3-O- $\beta$-D-glucuronide.

Among the ten compounds, EA is a plant-derived polyphenol with antiinflammatory, antioxidant, gastroprotective, hepatoprotective and anti-mutagenic effects. Its gastric protective mechanisms in ethanol-induced acute gastric ulcers have not been specifically elucidated and described. Therefore, the anti-ulcer activities of EA were evaluated in ethanol-induced acute gastric ulcer models in KM mice.

\section{Effect of EA on Inflammatory Factors in Gastric Ulcer Tissues of Mice}

After administration with anhydrous ethanol, the IL-10 level in gastric tissues were significantly decreased while the IL-6 and TNF- $\alpha$ levels were on the contrary $(P<0.05)$. In addition, the IL-10 level in the gastric tissues of EA were markedly increased in comparison to that of the model group $(P<0.05$ or $P<0.01)$, while the IL- 6 and TNF- $\alpha$ levels were significantly reduced $(P<0.05)$. Obviously, the reduction of TNF- $\alpha$ in the middle-dose of EA was more significant than that in the low-dose and high-dose EA groups (Fig. 2). 
The serum GAS contents of model group were significantly higher than those of the normal control group, however, the $\mathrm{COX}-2$ and $\mathrm{PGE}_{2}$ contents were on the contrary $(P<0.05)$. Additionally, the administration of middle-dose and high-dose EA showed a noticeable reduction in the GAS levels of serum $(P<0.05)$, while the $\mathrm{PGE}_{2}$ levels were significantly elevated compared with that of model group $(P<0.01)$ (Fig. 3).

\section{Effects of EA on ALT, AST and Cr in Gastric Ulcer Tissues of Mice}

The ALT, AST and Cr activities were significantly elevated in the model group in comparison to the normal control group $(P<0.05)$. The ALT and AST levels in the highdose EA group were significantly lower than that of the normal control group, model group and omeprazole group $(P<0.01)$. Moreover, the ALT, AST and Cr levels in the middle-dose EA group were close to the positive control omeprazole group $(P<0.05)$ (Fig. 4).

\section{Gross appearance of the gastric mucosa}

The gastric mucosal membrane surface of the normal control group (Fig. 5A) was smooth and intact with no hyperemia. In model group (Fig. 5B), a number of punctual ulcers distributed in mucosa were observed. There were some hyperemia points and a small ulcer area can be found in the omeprazole group (Fig. 5C). In the EA administration group (Fig. 5D, 5E and 5F), the degree of punctual bleeding, damage of gastric mucosa, and the area of gastric ulcers in mice were attenuated, suggesting that the EA has a protective effect on ethanol-induced acute gastric ulcer in the mice.

\section{Effects of EA on Gastric Lesions Histology}

In order to evaluate the status of gastric mucosa in ulcer mice, H\&E staining was performed on stomach sections of different groups. The gastric tissue of the normal control group (Fig. 6A and 6a) is dense and well-structured, the mucosal layer and muscular layer are clearly visible, and there are no apparent pathological changes such as tissue hemorrhage or inflammatory cell infiltration. The model group mice (Fig. 6B and 6b) administrated absolute ethanol without medical therapy produced several necrotic cell fragments and a large number of infiltrated inflammatory cells. Besides, the smooth muscle structure in the model group was disordered, the superficial gastric epithelium was disrupted and exfoliated and there were vacuoles and cell damage appear in the local gastric glands. In the omeprazole group (Fig. 6C and 6c), the glands were arranged consistently and there is a small amount of inflammatory cell infiltration. The mice that administrated pretreatment with EA displayed significant protection of the gastric mucosa (Fig. 6D, 6d, 6E, 6e, 6F and 6f), most areas of the stomach tissue of the mice are clearly structured, the cells are arranged neatly, and the degree of gland 
damage is less, which is significantly enhanced versus with the model group. Among them, the gastric tissues of mice in the low dose EA group have no difference from the normal group and the mucosal and muscle layer are clearly visible and textured, and only a few inflammatory cells were infiltrated.

\section{Effects of EA on Hepatic Histology}

Fig.7 shows the results of $\mathrm{H} \& \mathrm{E}$ staining of liver tissue in ulcer mice. The liver tissue structure of the mice in normal group (Fig. 7A and 7a) was complete with clear layout, round and full hepatocytes, and obvious boundary between the liver sinusoid and liver plate. In the model group (Fig. 7B and 7b), the liver tissue structure of mice was still clear, however, the liver cells were loose, the liver sinusoids were narrowed, and there were significant inflammatory cell infiltration and inflammatory response. The liver tissue of the mice in the omeprazole group (Fig. 7C and 7c) were arranged neatly, and a small number of vacuoles could be seen, but no obvious inflammatory cell infiltration was observed. Compared with the model group, the liver tissue of mice in the EA group was intact, with no obvious liver damage, and the degree of inflammatory cell infiltration was improved in a dose-dependent manner. The low dose of EA had a significant protective effect on the liver.

\section{Effects of EA on Nephridial Histology}

As shown in Fig.8, no significant histological changes were observed in the kidney of mice in the normal group, the omeprazole group and the groups administrated with different doses of EA. The kidneys of the model group had a larger glomerulus and wider lumen of the renal tubules, and the epithelial cells of renal tubulars were markedly damaged. Therefore, EA administered to mice was safe and no drug-related toxicity was detected even at the highest doses investigated.

\section{Discussion}

It has been reported that the natural secondary metabolites found in ethno-medicinal plants have antioxidants, especially polyphenols, which have a variety of functions to counteract the free radicals and regulate oxidative stress in cells [18]. And there is growing evidence that the use of medicinal plants is an alternative for the treatment of several gastrointestinal disorders, including gastric ulcers. The bio-active natural products with gastroprotective properties and a few side effects could substitute existing synthetic drugs. EA is a common metabolite present in many medicinal plants and its antioxidant property is responsible for many pharmacological activities, including altering inflammatory mediators (IL-6, IL-1 $\beta$ and TNF- $\alpha$ ) [19]. 
In this study, we have isolated and identified ten compounds from Eucalyptus citriodora leaves and investigated the protective effects of ellagic acid extracted from Eucalyptus citriodora leaves on ethanol-induced acute gastric ulcer in mice. The mice administrated anhydrous ethanol $(0.1 \mathrm{~mL} / 10 \mathrm{~g})$ had produced acute gastric ulcers and inflammatory responses, such as bleeding, edema, and erosion in the gastric tissues. However, the mice pretreated with various concentrations of EA significantly caused a reduction in the gastric injury, and the pathological changes of gastric ulcer were improved considerably, especially in the middle-dose group.

Inflammation is an important pathogenesis of gastric ulcers. The inflammatory cells will be affected to overreact and produce inflammatory factors (TNF- $\alpha$, IL- 6 and IL-10) when the gastrointestinal tract is stimulated by alcohol [20]. The proinflammatory cytokine TNF- $\alpha$ is associated with inflammation and injury of various tissues, and it will be secreted at the onset of gastric ulcer [21]. It is reported that increasing TNF- $\alpha$ will lead to severe damage to gastrointestinal mucosal by stimulating the neutrophil accumulation [22]. IL-6 is a multifunctional cytokine and is a direct immune response to inflammation caused by infection and tissue damage [23]. During gastric ulcer, elevated IL-6 level will stimulate lymphocytes and neutrophils which result in damages [24]. IL-10 is a counter-regulatory cytokine in inflammatory responses, and it can slow down the production of pro-inflammatory cytokines to damp down inflammation [25]. In this study, the TNF- $\alpha$ and IL-6 levels in the gastric tissues of the absolute ethanol group significantly increased, while the IL-10 level were considerably reduced. The increased levels of TNF- $\alpha$ and IL-6, and the decreased level of the IL-10 indicated injury and inflammation in the gastrointestinal tissues. Reversely, the TNF- $\alpha$ and IL-6 levels were significantly reduced, and the level of the IL-10 were expressively increased in the gastric tissues of the ellagic acid groups. Furthermore, the mice pretreated with EA showed a significant reduction in the degree of hemorrhagic damage and infiltration of inflammatory cells, which manifested EA has a good antiinflammatory effect and protective effect on ethanol-induced acute gastric ulcer in the mice, especially in the middle dose $(100 \mathrm{mg} / \mathrm{kg})$ EA group. The anti-inflammation effect of EA was more significant at the middle dose; however, the high dose EA (200 $\mathrm{mg} / \mathrm{kg}$ ) showed a more positive effect on reducing the IL-6 level and increasing the IL10 level. The exact mechanism of this effect has not figure out yet. Therefore, we proposed various hypotheses to explain this phenomenon. Firstly, EA exhibited protective effects against free radical damage in gastric ulcers, which may account for its antioxidant activity [26]. EA has the antioxidant activity of scavenging free radicals and inhibiting lipid peroxidation, which depends on EA concentration. Secondly, the high dose EA may stimulate physiological response mechanism which can lead to the changes in many physiological pathways, thus may have adverse effects on the antiulcer activity [27]. Thirdly, EA is known as a good chelator, and the chelating ability is positive correlated with its concentration. So that, high dose EA can more chelate with calcium ion in the extracellular or cytoplasm to change net concentration of free calcium. Meanwhile, the calcium gradient is associated with many signaling cascades, it means that high dose EA can more significantly stimulate these signaling cascades to affect the potency on gastric ulcer [28]. 
Gastrin (GAS) has an effect on stimulating gastric acid secretion, but excessive gastric acid secretion will lead to changes in gastric mucosal permeability and accelerate the formation of gastric ulcers [29]. In this research, the level of GAS significantly increased in the anhydrous ethanol group while GAS level decreased significantly in the middle dose EA group, and it is shown that middle dose EA has an ability on protecting gastric mucosa by decreasing GAS level.

COX-2 is an important inducing enzyme in the process of inflammation and it is a key enzyme that catalyzes the synthesis of arachidonic acid into prostaglandin (PG), mainly $\mathrm{PGE}_{2}$ [30]. $\mathrm{PGE}_{2}$ established clearly the important contributions in the protection of gastric mucosa [31]. In this study, the COX-2 contents of the model group were significantly higher than those of the normal control group while the $\mathrm{PGE}_{2}$ contents were significantly lower than those of the normal group. However, pretreated with EA, the COX-2 level significantly decreased while the $\mathrm{PGE}_{2}$ level significantly increased, and both were dose dependent.

Drug toxicity is the most common cause of acute liver and kidney failure; thus, it is necessary to identify and monitor the toxicity signals during clinical practice. The levels of alanine aminotransferase (ALT) and aspartate aminotransferase (AST) in serum are predictive of the likelihood of drug-induced liver injury [32]. Serum creatinine $(\mathrm{Cr})$ concentration is widely used as an indicator of renal function in clinics. In detail, serum creatinine is one of the main criteria for evaluation of steady-state, chronic kidney disease and acute kidney injury [33,34]. In this study, liver enzyme activities (ALT and AST) as well as creatinine levels were not negatively affected in the low/middle dose EA group, however, the ALT and AST activities in the high dose EA group were significantly decreased which indicating the injury in the liver of the high concentration EA.

\section{Conclusions}

Eucalyptus citriodora leaves are the rich source of polyphenol and flavonoid compounds and exhibit strong antioxidant and anti-inflammatory properties, which have potential to develop the drugs of antioxidant, gastroprotective and antiinflammatory. We have extracted and identified ten compounds from Eucalyptus citriodora leaves and investigated the effects on anti-ulcer and anti-inflammatory against ethanol-induced acute gastric ulcer of ellagic acid that is a polyphenol compound of extraction. The present findings evidence that middle dose $(100 \mathrm{mg} / \mathrm{kg})$ EA have significant effect on anti-gastric ulcer and anti-inflammatory through increase the IL-10 and PGE 2 levels, and reduce the IL-6, TNF- $\alpha$, GAS and COX-2 levels. Furthermore, the ALT, AST and $\mathrm{Cr}$ contents in the middle dose EA have few differences from the normal group, which indicate that it has no adverse effect on liver and kidney. These results uncover that ellagic acid may be a good candidate for development as an anti-ulcer drug. 


\section{Materials and Methods}

\section{Chemical and Reagent}

Ethanol, petroleum ether, ethyl acetate, chloroform, Methanol and acetone were procured from Guangdong Guanghua Technology Co. Ltd. (Guangdong, China). N$\mathrm{BuOH}$ was obtained from Tianjin DaMao Chemical Reagent Factory. (Tianjin, China). DIAION HP2MGL Macroporous resin was obtained from Mitsubishi. (Japan). Sephadex LH-20 was obtained from Cytiva. (America). Omeprazole (OME) was obtained from CSPC Ouyi Pharmaceutical Co. Ltd. (Hebei, China). The enzyme-linked immunosorbent assay (ELISA) kits for determination of IL-6, IL-10, TNF- $\alpha$, ALT, AST, GAS, PGE 2 , COX-2 and Cr were obtained from Shanghai MLBIO Biotechnology Co. Ltd. (Shanghai, China). All other chemicals and reagents used were of analytical grade.

\section{Plant Material}

Eucalyptus citriodora leaves was collected at the Lingnan Normal University, Guangdong, China. It was authenticated by one of the authors (Zhongliu Zhou) and a voucher specimen (EC 2020/9) was deposited at the Natural Medicinal Chemistry Lab of the university.

\section{Extraction of Plant Material}

The Eucalyptus citriodora leaves (12 kg) was dried, ground and extracted with $95 \%$ EtOH $(5 * 10 \mathrm{~L})$. The solution collected was concentrated under reduced pressure and then dispersed into distilled water. The solution obtained successively extracted with petroleum ether, ethyl acetate and water-saturated n-BuOH. The water-saturated n$\mathrm{BuOH}$ fraction $(160 \mathrm{~g})$ was fractionated using DIAION HP2MGL macroporous resin column chromatography eluting with $\mathrm{H}_{2} \mathrm{O} / \mathrm{EtOH}(1: 0,7: 3,5: 5,3: 7,1: 19)$ to acquired five fractions. Fraction $3(40 \mathrm{~g})$ was separated using silica gel column eluting with chloroform/ $\mathrm{MeOH} / \mathrm{H}_{2} \mathrm{O}$ (9:1:0.1, 8:2:0.2, 7:3:0.5, 6:4:1), and then was purified by Sephadex LH-20 column eluting with MeOH and LC-100 semi-preparative HPLC $(\mathrm{C} 18,10.0 * 250 \mathrm{~mm}, 5 \mu \mathrm{m})$ using $\mathrm{MeOH} / \mathrm{H}_{2} \mathrm{O}(60: 30$ to $100: 0)$ to obtain ten compounds.

\section{Animals}

The animal experiments were conducted according to the rules of animal experiment and the protocol also followed the rules of the local Animal Ethics Committee (Ethic Permit TCMF1-2014025). Forty-eight male mice (20-25 g) were purchased from the 
Guangdong Medical Laboratory Animal Center (Guangdong, China). The mice were placed in suitable cages with inert husk materials as bedding and were maintained under controlled environment conditions of light and dark cycle (light $12 \mathrm{~h}$, dark $12 \mathrm{~h}$, temperature $23 \pm 2{ }^{\circ} \mathrm{C}$ and relative humidity $55 \pm 10 \%$ ) for a period of 1 week before starting the experiments. The animals were provided free access to water and standard chow pellets.

\section{Experimental design}

The mice were randomly assigned to six groups, containing normal group, model group, omeprazole group and high / meddle / low dose of Ellagic acid. All groups successively received corresponding drugs once a day $(0.1 \mathrm{~mL} / 10 \mathrm{~g})$ for fourteen days by a gastric gavage. (Normal group and model group administrated normal saline.)

\section{Induction of acute gastric ulcer and sample collection}

On the last day of giving drugs, 60 mins after drug administration, the mice were not in normal group received absolute ethanol $(0.2 \mathrm{~mL} / 10 \mathrm{~g})$ by a gastric gavage, while normal group received normal saline [35]. After $1 \mathrm{~h}$, removed the eyeballs of the mice and the blood was collected under $4{ }^{\circ} \mathrm{C}$ and centrifuged at $4000 \mathrm{rpm}$ for $10 \mathrm{~min}$ to obtain serum preserving at $-20{ }^{\circ} \mathrm{C}$ for biochemical estimation. The mice were sacrificed by cervical dislocation, the stomach was removed, opened along the greater curvature and rinsed gently in normal saline. The stomach, kidney and liver tissues were collected and rinsed with normal saline and then fixed into $4 \%$ paraformaldehyde solution, processed for histological, immunohistochemical, and biochemical assessments.

\section{Histopathological evaluation}

After the stomach, kidney and liver tissues were fixed in 4\% paraformaldehyde solution for $24 \mathrm{~h}$, these tissues were dehydrated using a series of alcohol, cleared in xylene and then treated with paraffin imbedding. Tissues were cut into $5 \mu \mathrm{m}$ thickness, stained with Hematoxylin-eosin and were performed to observe the histopathological changes of these samples under a light microscope.

\section{Liver tissue levels in mice}

The livers from the mice were processed into piece and added pre-cooled saline $(5 \mathrm{~mL} / 10 \mathrm{~g})$ and then homogenate in the ice-bath and centrifuged under $4{ }^{\circ} \mathrm{C}$ at 4000 rpm for 10 min to obtain serum. The levels of alanine aminotransferase (ALT) and 
aspartate aminotransferase (AST) in the liver tissue were determined according to the kit instructions (Shanghai MLBIO Biotechnology Co. Ltd.).

\section{Serum levels in mice}

The level of IL-6, IL-10, TNF- $\alpha$, GAS, COX-2, PGE 2 and $\mathrm{Cr}$ in the serum were determined according to the kit instructions (Shanghai MLBIO Biotechnology Co. Ltd.).

\section{Statistical analysis}

The results from each group were calculated as mean \pm standard error of mean (S.E.M.). They were analyzed by one-way analysis of variance (ANOV A), and the statistical evaluation between two groups was determined by LSD on SPSS 20.0. Probability $(P)$ values less than $0.05(P<0.05)$ were considered to be statistically significant.

\section{Acknowledgments}

This research was financially supported by the following projects:

\section{Funding}

This work was financed by the National Natural Science Foundation of China (grant nos. 81904104 and 31900297); the Lingnan Normal University-level talent project (grant no. ZL1801 and QL1401); the Natural Science Foundation of Guangdong province of China (grant no. 2018A030307037); the Yanling excellent young teacher program of Lingnan Normal University (grant no. YL20200210); the Guangdong Provincial key discipline scientific research project (2019-GDXK-0025); National Training Program of Innovation and Entrepreneurship for Undergraduates (grant no. 202010579006); the Scientific Research Project of the Administration of Traditional Chinese Medicine of Guangdong Province, China (grant no. 20211203); and the China Postdoctoral Science Foundation (grant no. 2021M690759).

\section{Conflict of Interest}

The authors declare that they have no conflict of interest.

\section{Ethical approval}

All applicable international, national, or institutional guidelines for the care and use of animals were followed. 


\section{References}

1. Makola D, Peura DA, Crowe SE. Helicobacter pylori infection and related gastrointestinal diseases. Journal of Clinical Gastroenterology. 2007;41(6):548558. https://doi.org/10.1097/MCG.0b013e318030e3c3.

2. Tuorkey M, Karolin K. Anti-ulcer activity of Curcumin on experimental gastric ulcer in rats and its effect on oxidative stress/antioxidant, IL-6 and enzyme activities. Biomedical and Environmental Sciences. 2009;22(6):488-495. https://doi.org/10.1016/S0895-3988(10)60006-2.

3. Lodato F, Azzaroli F, Turco L, Mazzella N, Buonfiglioli F, Zoli M et al. Adverse effects of proton pump inhibitors. Best Practice \& Research Clinical Gastroenterology. 2010;24(2):193-201. https://doi.org/10.1016/j.bpg.2009.11.004.

4. Falcão HS, Mariath IR, Diniz MF, Batista LM, Barbosa-Filho JM. Plants of the American continent with antiulcer activity. Phytomedicine. 2008;15(1-2):132-146. https://doi.org/10.1016/j.phymed.2007.07.057.

5. Jesus NZ, Falcão HS, Lima GR, Caldas Filho MR, Sales IR, Gomes IF et al. Hyptis suaveolens (L.) Poit (Lamiaceae), a medicinal plant protects the stomach against several gastric ulcer models. J Ethnopharmacol. 2013;150(3):982-988. https://doi.org/10.1016/j.jep.2013.10.010.

6. Beserra AMSeS, Calegari PI, Souza MdC, dos Santos RAN, Lima JCdS, Silva $\mathrm{RM}$ et al. Gastroprotective and ulcer-healing mechanisms of ellagic acid in experimental rats. Journal of Agricultural and Food Chemistry. 2011;59(13):69576965. https://doi.org/10.1021/jf2003267.

7. Murakami S, Isobe Y, Kijima H, Nagai H, Muramatu M, Otomo S. Inhibition of gastric $\mathrm{H}+, \mathrm{K}(+)$-ATPase and acid secretion by ellagic acid. Planta medica. 1991;57(4):305-308. https://doi.org/10.1055/s-2006-960103.

8. Dan C, Jiao W. Chemical constituents of Caryophylli Flos. Chinese Medicinal Materials. 2018;41(05):1108-1113. https://doi.org/10.13863/j.issn10014454.2018.05.020.

9. Ye G, Fan MS, Huang CG. Ellagic acid glycosides from the stem bark of Aphananthe aspera. Chemistry of Natural Compounds. 2007;43(5):558-559. https://doi.org/10.1007/s10600-007-0191-1.

10. Guo WJ, Yu J, Zhu DW, Chen XH, Hou WZ. Chemical constituents of the artificial fruit body of Antrodia cinnamomea. Chemistry of Natural Compounds. 2020;56(4):777-779. https://doi.org/10.1007/s10600-020-03148-2.

11. Wu L, Wu J, Chen SP, Li ZJ, Zhang J, Yuan E et al. Chemical constituents of the twigs of Elaeocarpus sylvestris. Chemistry of Natural Compounds. 2019;55(2):324-326. https://doi.org/10.1007/s10600-019-02679-7.

12. Gao LM, Wu LJ, Huang J, Sun BH, Gao HY. Chemical constituents from the flowers of Castanea mollissima Blume. Journal of Shenyang Pharmaceutical University. 2010;27(07):544-547. https://doi.org/10.14066/j.cnki.cn211349/r.2010.07.004. 
13. Wu T, Abdulla R, Yang Y, Aisa HA. Flavonoids from Gossypium hirsutum flowers. Chemistry of Natural Compounds. 2008;44(3):370-371. https://doi.org/10.1007/s10600-008-9067-2.

14. Benkiniouar R, Rhouati S, Touil A, Seguin E, Chosson E. Flavonoids from Thymus algeriensis. Chemistry of Natural Compounds. 2007;43(3):321-322. https://doi.org/10.1007/s10600-007-0118-X.

15. Zhuang JY, Li BS, Wang SY. Study on the anti-diabetic activities of Tamarindus pericarp. Modern Food Science and Technology. 2011;27(07):773-776. https://doi.org/10.13982/j.mfst.1673-9078.2011.07.004.

16. Jung MJ, Jung HA, Kang SS, Hwang GS, Choi JS. A new abietic acid-type diterpene glucoside from the needles of Pinus densiflora. Archives of Pharmacal Research. 2009;32(12):1699-1704. https://doi.org/10.1007/s12272-009-2206-X.

17. Vijayalakshmi A, Geetha M. Anti-psoriatic activity of flavonoids from Cassia tora leaves using the rat ultraviolet $\mathrm{B}$ ray photodermatitis model. Revista Brasileira De Farmacognosia-Brazilian Journal of Pharmacognosy. 2014;24(3):322-329. https://doi.org/10.1016/j.bjp.2014.07.010.

18. Tresserra-Rimbau A, Lamuela-Raventos RM, Moreno JJ. Polyphenols, food and pharma. Current knowledge and directions for future research. Biochemical Pharmacology. 2018;156:186-195. https://doi.org/10.1016/j.bcp.2018.07.050.

19. Rios JL, Giner RM, Marin M, Recio MC. A pharmacological update of ellagic acid. Planta Medica. 2018;84(15):1068-1093. https://doi.org/10.1055/a-06339492.

20. Patel S, Behara R, Swanson GR, Forsyth CB, Voigt RM, Keshavarzian A. Alcohol and the intestine. Biomolecules. 2015;5(4):2573-2588. https://doi.org/10.3390/biom5042573.

21. Hamaguchi M, Watanabe T, Higuchi K, Tominaga K, Fujiwara Y, Arakawa T. Mechanisms and roles of neutrophil infiltration in stress-induced gastric injury in rats. Digestive Diseases and Sciences. 2001;46(12):2708-2715. https://doi.org/10.1023/A:1012779530004.

22. Wei XM, Heywood GJ, Di Girolamo N, Thomas PS. Nicorandil inhibits the release of TNF- $\alpha$ from a lymphocyte cell line and peripheral blood lymphocytes. International Immunopharmacology. 2003;3(12):1581-1588. https://doi.org/10.1016/S1567-5769(03)00176-0.

23. Kishimoto T. IL-6: from its discovery to clinical applications. Int Immunol. 2010;22(5):347-352. https://doi.org/10.1093/intimm/dxq030.

24. Navaei-Alipour N, Mastali M, Ferns GA, Saberi-Karimian M, Ghayour-Mobarhan $\mathrm{M}$. The effects of honey on pro- and anti-inflammatory cytokines: a narrative review. Phytotherapy Research. 2021;35(7):3690-3701. https://doi.org/10.1002/ptr.7066.

25. Rad R, Dossumbekova A, Neu B, Lang R, Bauer S, Saur D et al. Cytokine gene polymorphisms influence mucosal cytokine expression, gastric inflammation, and host specific colonisation during Helicobacter pylori infection. Gut. 2004;53(8):1082-1089. https://doi.org/10.1136/gut.2003.029736. 
26. Iino T, Tashima K, Umeda M, Ogawa Y, Takeeda M, Takata K et al. Effect of ellagic acid on gastric damage induced in ischemic rat stomachs following ammonia or reperfusion. Life Sciences. 2002;70(10):1139-1150. https://doi.org/10.1016/s0024-3205(01)01493-X.

27. Ou HC, Lee WJ, Lee SD, Huang CY, Chiu TH, Tsai KL et al. Ellagic acid protects endothelial cells from oxidized low-density lipoprotein-induced apoptosis by modulating the PI3K/Akt/eNOS pathway. Toxicology and Applied Pharmacology. 2010;248(2):134-143. https://doi.org/10.1016/j.taap.2010.07.025.

28. Vattem DA, Shetty K. Biological functionality of ellagic acid: a review. Journal of Food Biochemistry. 2005;29(3):234-266. https://doi.org/10.1111/j.17454514.2005.00031.x.

29. Gschwantler M, Dragosics B. Pathophysiology of Helicobacter pylori infection. Acta Medica Austriaca. 2000;27(4):117-121. https://doi.org/10.1046/j.15632571.2000.00028.x.

30. Samad TA, Moore KA, Sapirstein A, Billet S, Allchorne A, Poole S et al. Interleukin-1 $\beta$-mediated induction of COX-2 in the CNS contributes to inflammatory pain hypersensitivity. Nature. 2001;410(6827):471-475. https://doi.org/10.1038/35068566.

31. Wallace JL. Prostaglandins, NSAIDs, and gastric mucosal protection: Why doesn't the stomach digest itself? Physiological Reviews. 2008;88(4):1547-1565. https://doi.org/10.1152/physrev.00004.2008.

32. Abboud G, Kaplowitz N. Drug-induced liver injury. Drug Safety. 2007;30(4):277294. https://doi.org/10.2165/00002018-200730040-00001.

33. Bjornsson TD. Use of serum creatinine concentrations to determine renal function. Clinical Pharmacokinetics. 1979;4(3):200-222. https://doi.org/10.2165/00003088197904030-00003.

34. Kashani K, Rosner MH, Ostermann M. Creatinine: From physiology to clinical application. European Journal of Internal Medicine. 2020;72:9-14. https://doi.org/10.1016/j.ejim.2019.10.025.

35. Olatunji OJ, Chen HX, Zhou YF. Anti-ulcerogenic properties of Lycium chinense mill extracts against ethanol-induced acute gastric lesion in animal models and its active constituents. Molecules. 2015;20(12):22553-22564. https://doi.org/10.3390/molecules201219867. 
<smiles>O=c1oc2c(O)c(O)cc3c(=O)oc4c(O)c(O)cc1c4c23</smiles>

(1)<smiles>O=c1c(O)c(-c2ccc(O)c(O)c2)oc2cc(O)cc(O)c12</smiles>

(3)<smiles>COc1c(O)cc2c(=O)oc3c(O)c(OC4OC(C)C(O)C(O)C4O)cc4c(=O)oc1c2c34</smiles>

(5)<smiles></smiles>

(7)

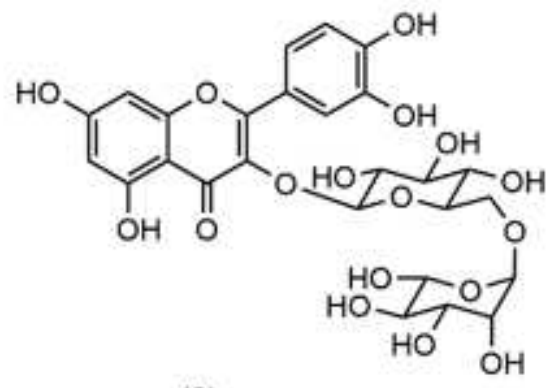

(9)<smiles>O=C(O)c1cc(O)c(O)c(O)c1</smiles>

(2)<smiles>O=c1c(O)c(-c2cc(O)c(O)c(O)c2)oc2cc(O)cc(O)c12</smiles>

(4)<smiles>O=c1c(OC2OC(CO)C(CO)C(O)C2O)c(-c2ccc(O)c(O)c2)oc2cc(O)cc(O)c12</smiles>

(6)<smiles>O=C(O)C1C(O)OC2OC(O)C1C(O)C2Oc1c(-c2ccc(O)c(O)c2)oc2cc(O)cc(O)c2c1=O</smiles>

(8)<smiles>COc1cc2c(=O)oc3c(OC)c(OC4OC(CO)C(O)(CO)C(O)C4O)cc4c(=O)oc(c1OC)c2c34</smiles>

(10)

\section{Figure 1}

The chemical structures of the ten compounds isolated from Eucalyptus citriodora leaves were identified according to their $1 \mathrm{H}$ NMR and $13 \mathrm{C}$ NMR spectra. 

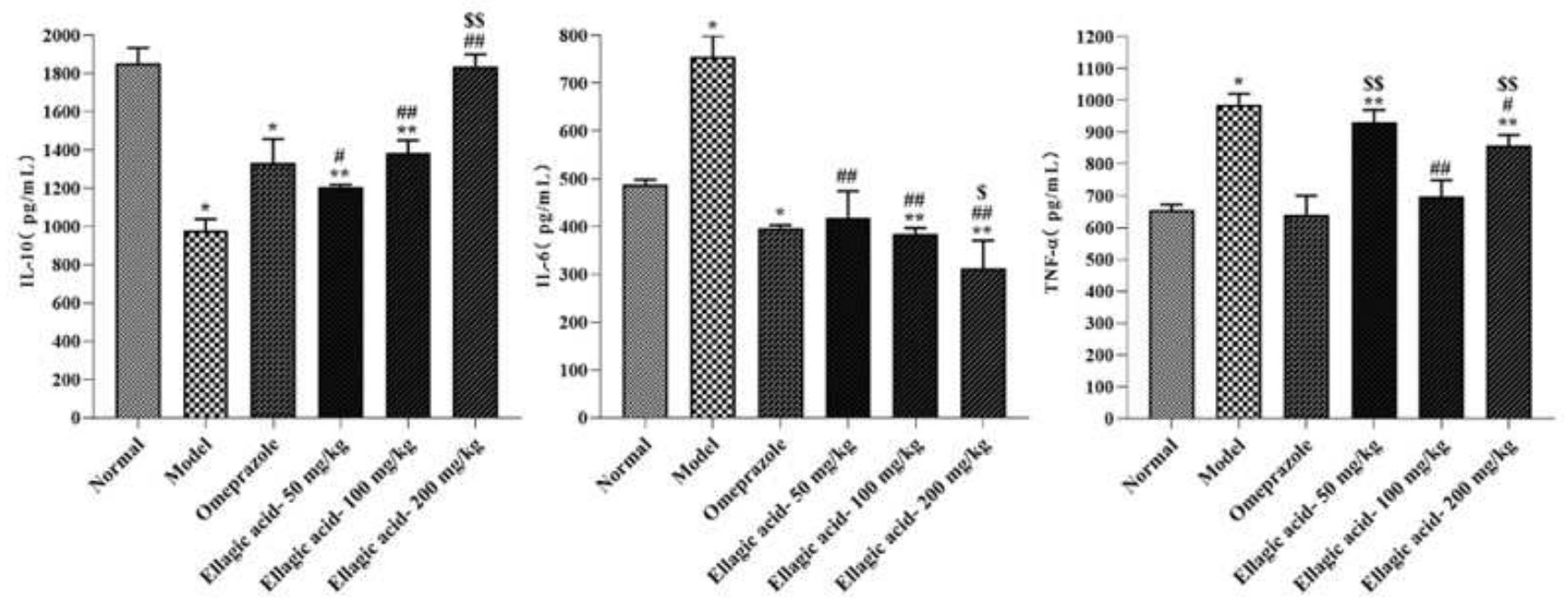

Figure 2

Effect of ellagic acid on serum of IL-10, IL-6 and TNF-a in mice. (Note: ${ }^{\star} P<0.05$, ${ }^{\star *} \mathrm{P}<0.01$ vs Normal; $\# \mathrm{P}<0.05, \# \# \mathbf{P}<0.01$ vs Model; $\$ \mathrm{P}<0.05, \$ \mathrm{P}<0.01$ vs Omeprazole)
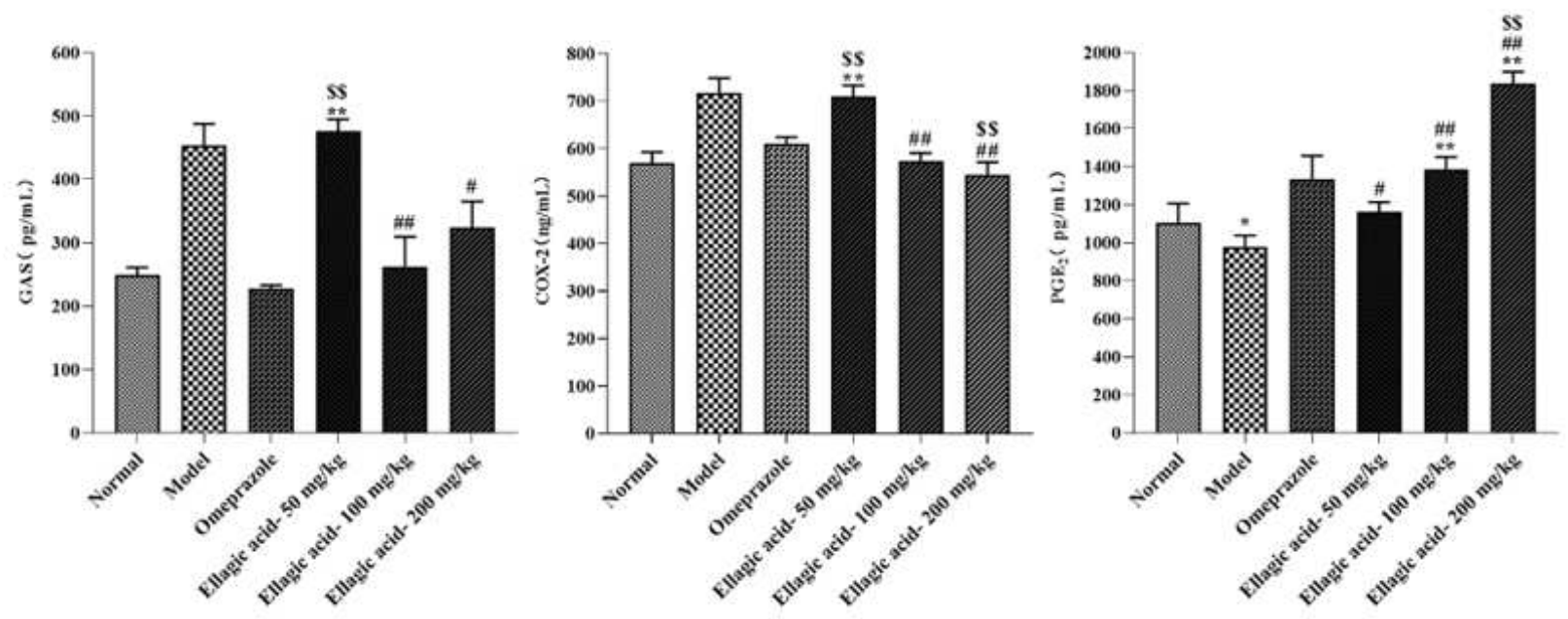

Figure 3

Effect of ellagic acid on serum of GAS, COX-2 and PGE2 in mice. (Note: ${ }^{*} \mathrm{P}<0.05,{ }^{\star *} \mathrm{P}<0.01$ vs Normal; $\# \mathrm{P}<0.05, \# \# \mathrm{P}<0.01$ vs Model; $\$ \mathrm{P}<0.05, \$ \$ \mathrm{P}<0.01$ vs Omeprazole) 

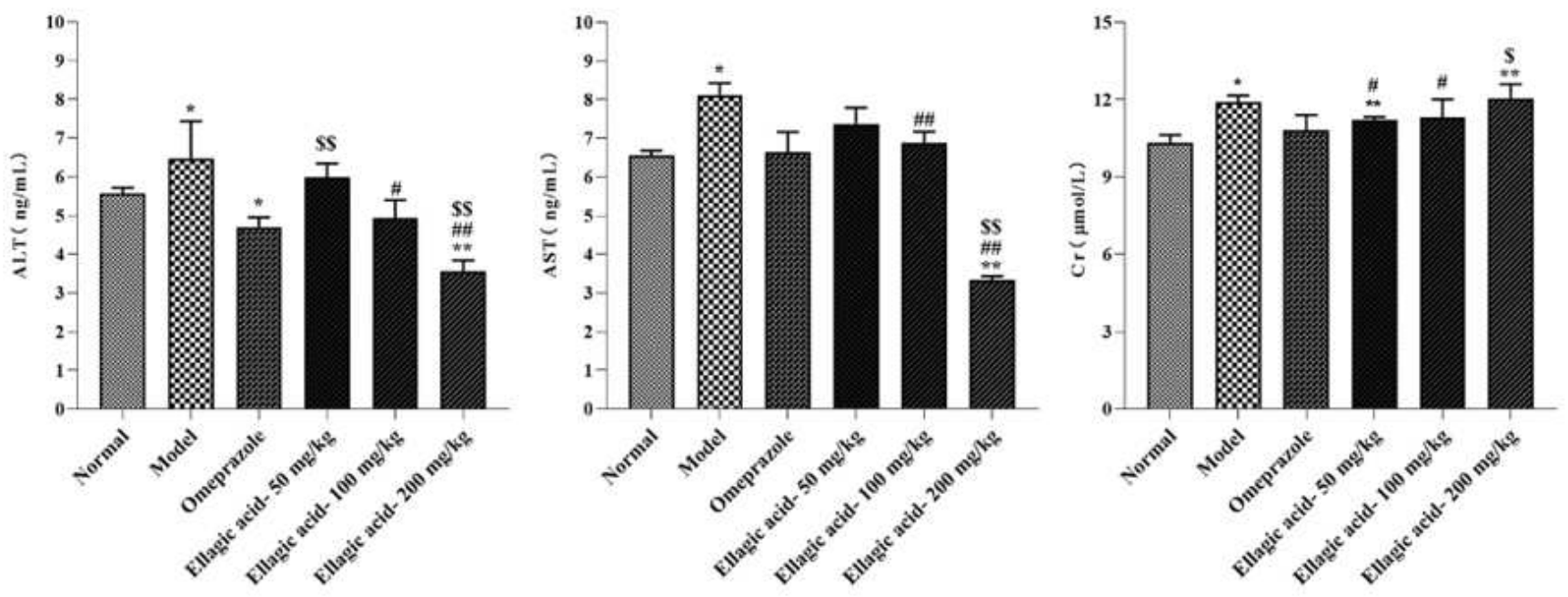

Figure 4

Effect of EA on serum of ALT, AST and Cr in mice. (Note: ${ }^{*} P<0.05$, ${ }^{\star *} \mathrm{P}<0.01$ vs Normal; $\# \mathrm{P}<0.05, \# \# \mathrm{P}<0.01$ vs Model; $\$ \mathrm{P}<0.05, \$ \$ \mathrm{P}<0.01$ vs Omeprazole)

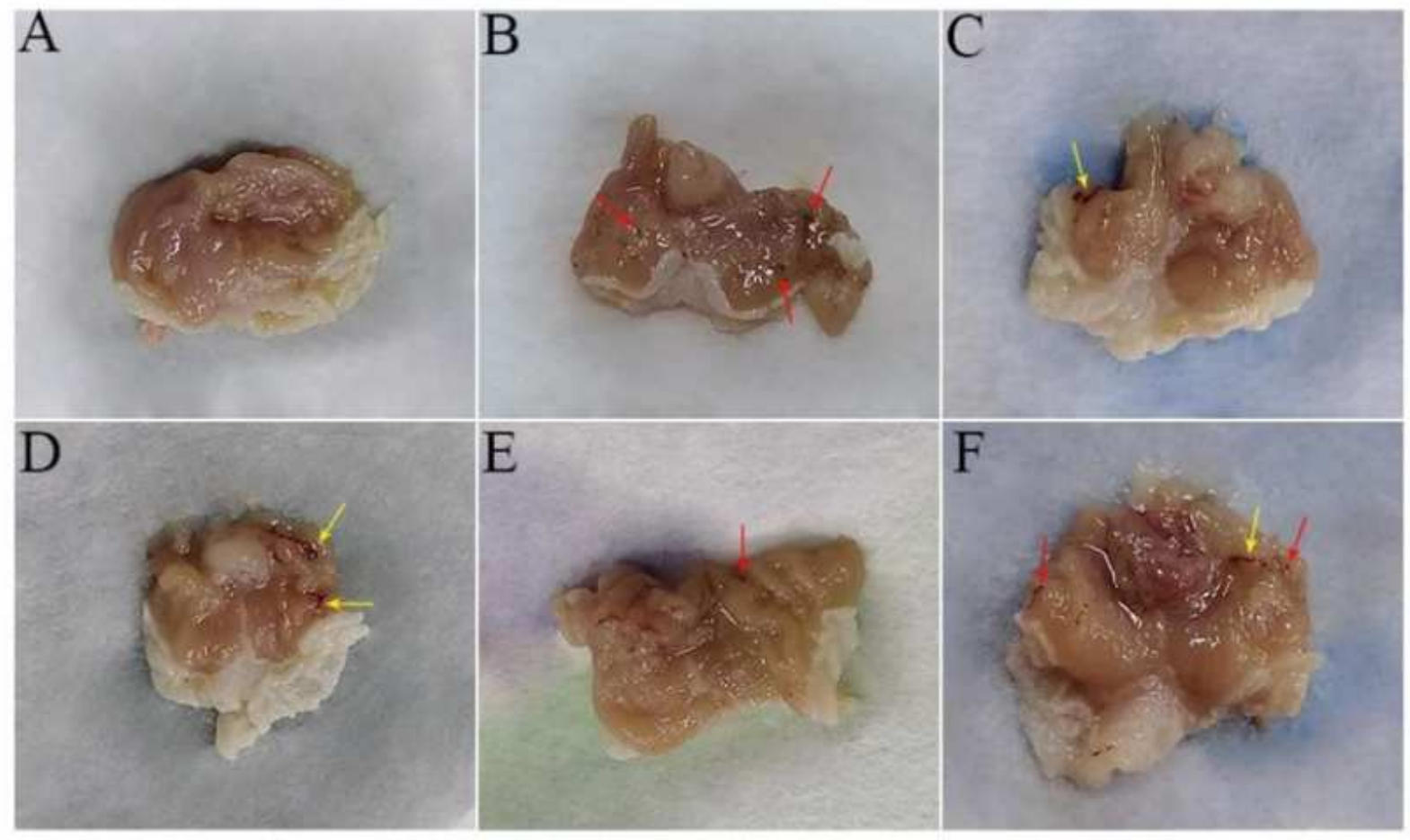

Figure 5

Effect of EA on gross appearance of the gastric mucosa in ethanol-induced acute gastric ulcer mice. (A) Normal group; (B) Model group; (C) Omeprazole group; (D) Low dose of EA group; (E) Medium dose of EA group; (F) High dose of EA group; Punctual ulcers (red arrows); Hyperemia points (yellow arrows). 


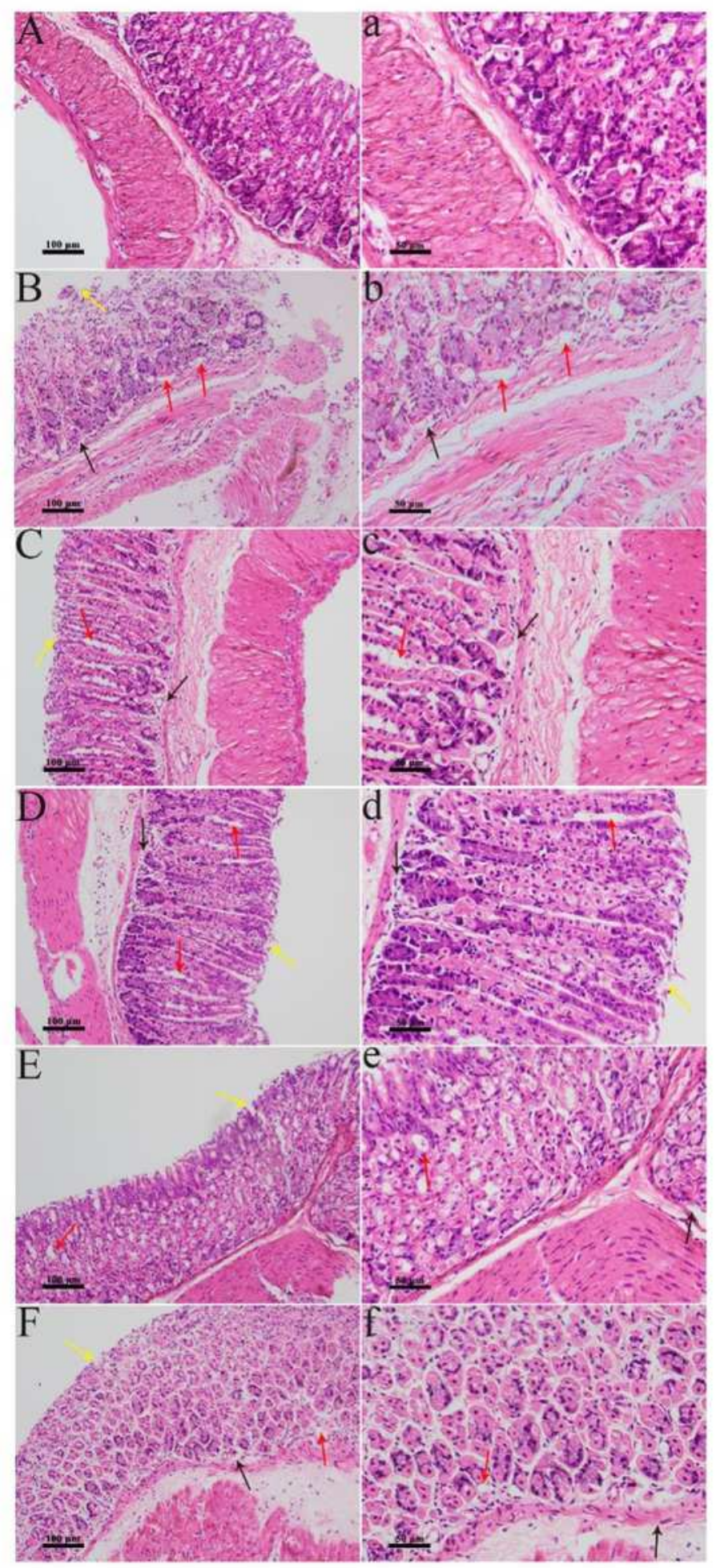

\section{Figure 6}

Effects of compound on histopathological gastric lesions in mice $(H E \times 100, \times 200)$. (A) Normal group HEx100, (a) Normal group HEx200; (B) Model group HEx100, (b) Model group HE×200; (C) Omeprazole group HEx100, (c) Omeprazole group HE×200; (D) Low dose of EA HEx100, (d) Low dose of Ellagic acid HEx200. (E) Medium dose of EA HEx100, (e) Medium dose of EA HEx200; (F) High dose of EA HEx100, (f) 
High dose of EA HE×200; Mucosa desquamation (black arrows); Edematous mucosa (red arrows); Local disruption of gastric mucosa (yellow arrows).

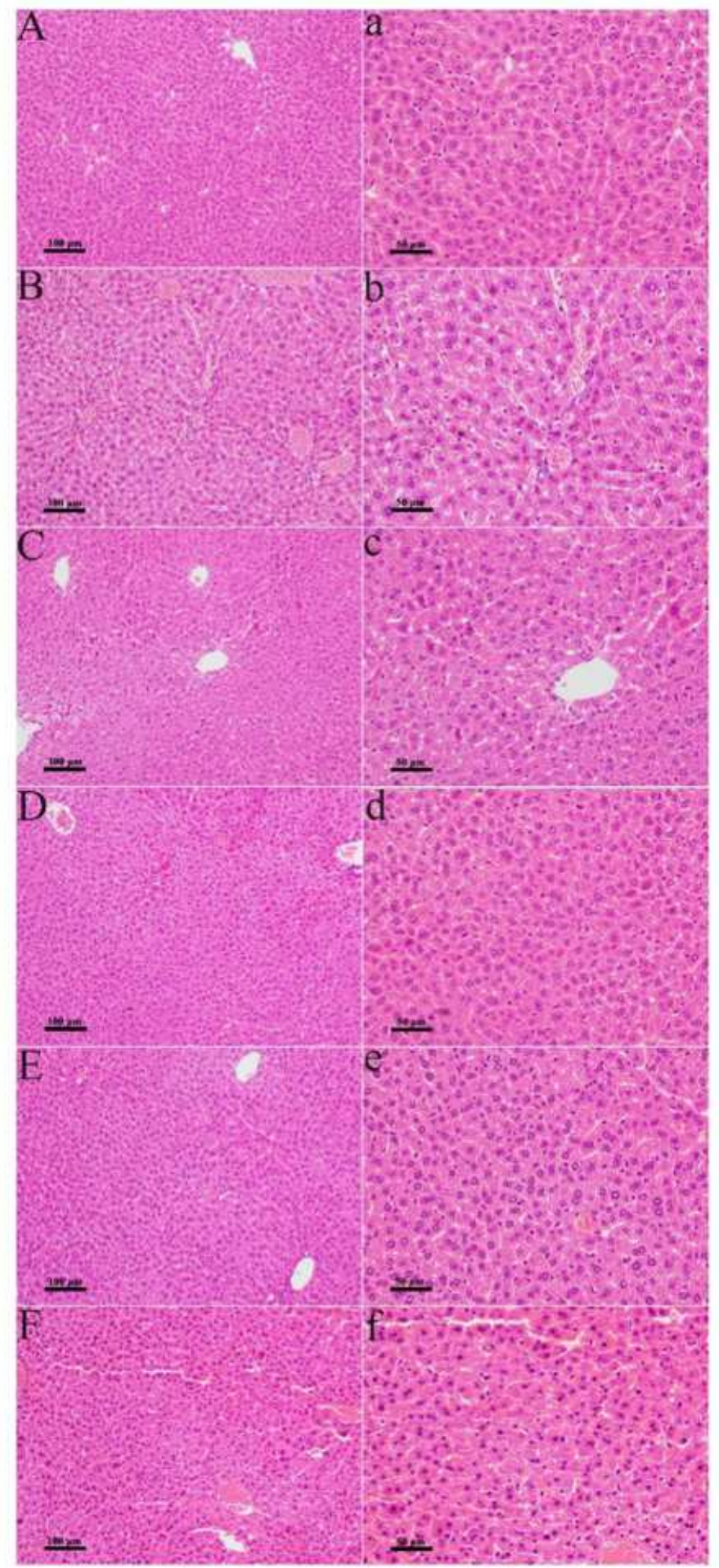

\section{Figure 7}

Effects of compound on histopathological liver lesions in mice $(H E \times 100, \times 200)$. (A) Normal group HEx100, (a) Normal group HE×200; (B) Model group HEx100, (b) Model group HE×200; (C) Omeprazole group HEx100, (c) Omeprazole group HE×200; (D) Low dose of EA HEx100, (d) Low dose of EA HE×200. 
(E) Medium dose of EA HEx100, (e) Medium dose of EA HEx200; (F) High dose of EA HEx100, (f) High dose of EA HEx200;

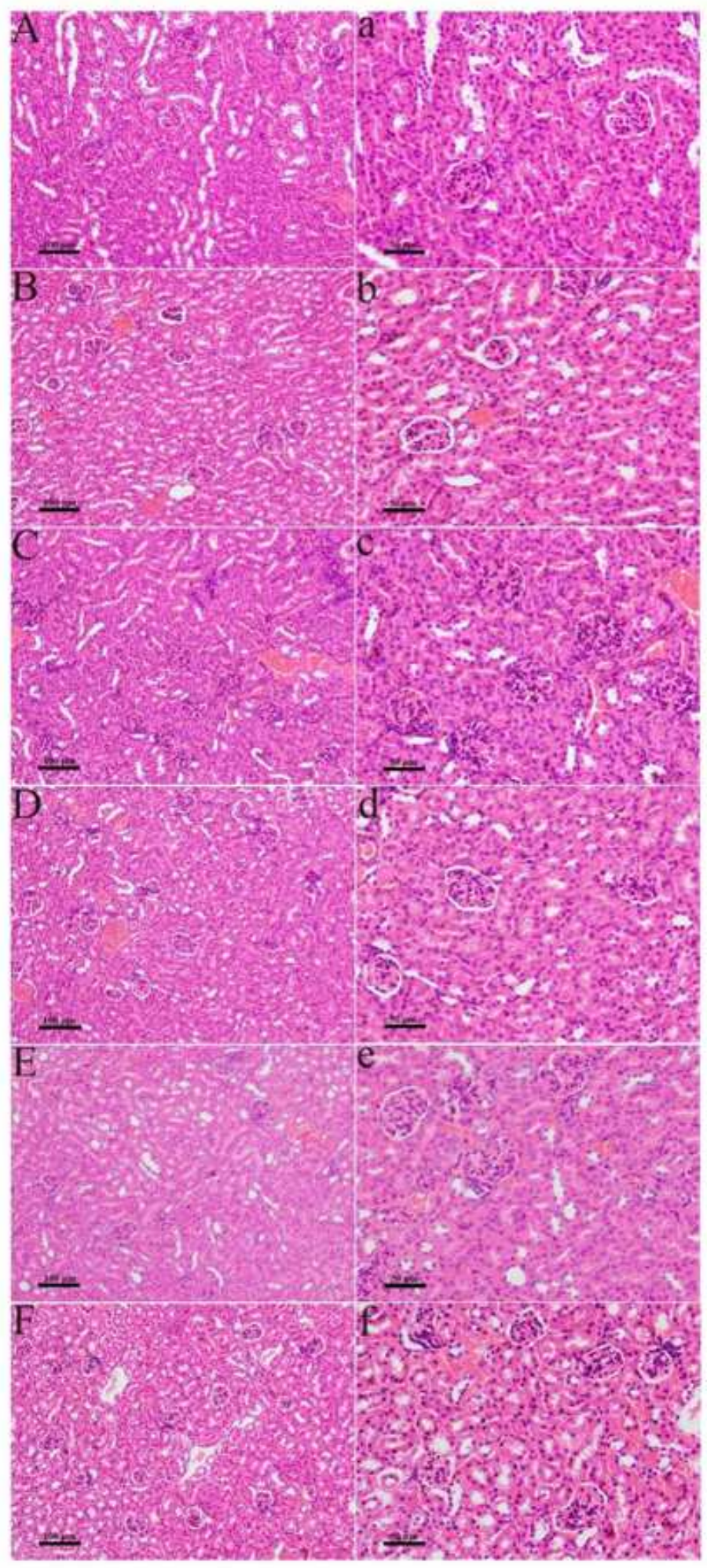

\section{Figure 8}

Effects of compound on histopathological nephridial lesions in mice $(H E \times 100, \times 200)$. (A) Normal group HEx100, (a) Normal group HE×200; (B) Model group HE×100, (b) Model group HE×200; (C) Omeprazole group HEx100, (c) Omeprazole group HE×200; (D) Low dose of EA HE×100, (d) Low dose of EA HE×200. 
(E) Medium dose of EA HEx100, (e) Medium dose of EA HE×200; (F) High dose of EA HEx100, (f) High dose of EA HEx200.

\section{Supplementary Files}

This is a list of supplementary files associated with this preprint. Click to download.

- GraphicalAbstract.tif

- Supportinformation.docx 